\title{
Review
}

\section{Critical theory and the challenge of praxis}

\author{
Stefano Giacchetti Ludovisi (ed) \\ Surrey, Ashgate, 2015, 240 pp., ISBN: 978-1472447739
}

Contemporary Political Theory (2019) 18, S5-S7. https://doi.org/10.1057/s41296-0170179-y; published online 5 December 2017

Stefano Giacchetti Ludovisi has compiled here an important and remarkably useful collection of essays that tackle the greatest concern of critical theory- that of praxis. Praxis is defined as action or engagement upon the world that seeks to create change. Marx gave us the legacy of praxis most famously in his eleventh thesis on Feuerbach: "The philosophers have only interpreted the world in various ways; the point is to change it." Critical theorists in the twentieth century, and now in the twenty-first, have worked to ascertain the agents and focus of such vital praxis. At its foundations, this book is important not so much because it brings together creative thinkers discussing interesting perspectives on radical social change, but rather simply because it exists-because its existence makes the argument that critical theory is a living philosophy, a breathing, and actively resisting, worldview. Critical theory is not merely a collection of works that engage early Marxian ideas to critique the many tentacles of hegemonic advanced capitalism; it is not merely a way to reference the combined works of the group of thinkers known collectively as the Frankfurt School. It is an approach that can be employed without limit, to seek alternatives to the dominance of technical reason, disciplinary modes of power, and false consciousness that govern our contemporary everyday lives.

This collection aims to address the contemporary usefulness of the works of first, second, and third generation critical theorists like Benjamin, Adorno, Horkheimer, Marcuse, Habermas, and Honneth. It seriously challenges the notion that critical theory is outdated and can no longer serve to illuminate the needs of praxis in the age of global capitalism. It further operates under the belief that critical theory can both function as a means to better understand the complexities of the twenty-first century, and as set of tools by which to carve out alternative ways to envision political praxis. The book's chapters were cultivated through participation in the international critical theory conferences that have been held yearly at the John Felice Rome Center of Loyola University Chicago since 2010.

(ㄷ) 2017 Macmillan Publishers Ltd., part of Springer Nature. 1470-8914 Contemporary Political Theory Vol. 18, S1, S5-S7 www.palgrave.com/journals 
The collection is comprised of fourteen essays, with an introductory chapter written by Ludovisi. He also writes the third essay in the volume, along with contributors Deborah Cook, Stefano Petrucciani, James Gordon Finlayson, Idit Dobbs-Weinstein, Karin Stogner, Rocio Zambrana, Andrew Feenberg, Robert Fine, Alessandro Ferrara, Marcos Nobre, David Ingram, Samir Gandesha, and Massimo Canevacci. The authors well represent the uniquely multi-disciplinary field that is critical theory. While most are philosophers, others teach political philosophy, sociology, social theory, modern European thought, and cultural anthropology. It is indicative of the power and usefulness of critical theory itself that such diversity of thinkers is engaged in not only studying the world through its lens, but in seeking revolutionary change through its lessons and mechanisms.

The chapter titles reflect the hard work of bridging theory with practice: "Realizing Philosophy", "How Practical Can Critical Theory Be?", and "Rethinking Critical Theory Once Again", among others. The fourteen essays are further organized into thematic sections, as explained by Ludovisi in the Introduction. The first part, comprised of chapters two through six, focuses on making contemporary use of Adorno's work to consider how a new understanding of Marxism can be employed in the world today, beginning with Deborah Cook, who argues that critical theory should seek out and aid the coming about of a new global subject that can pursue radical social change. The second section includes chapters seven to thirteen, and seeks to use critical theory to strengthen current discussions of rights and justice. This begins with Karin Stogner's chapter that aims to bridge the tension between individual acts and collective societal structures and history, in order to accurately critique and struggle against oppressive nationalistic and anti-Semitic claims and acts.

The final portion consists of chapters 14 and 15 and examines how aesthetics and politics interact within the context of critical theory. The last two essays examine the role of art, in this case color, and music, in contributing to emerging forms of political praxis. It is refreshing, and a unique strength of the book that these essays were included, as the role of art in praxis is too often diminished. Were a future volume created, I would appeal to the editor to maintain its well organized structure, but to include more essays that examine the experience of art, especially in our public and social spaces, and how such actions can (directly and indirectly) encourage wider radical change. In seeking new possibilities for praxis, revitalizing emotional and spiritual experiences of the visual and aural are needed in our communal places. These creative moments are sources of true freedom, of critical self-awareness and self-transformation, and thus potential action within the individual. They can aid in the perpetual struggle not only against false consciousness and instrumental reason, but against the numbing effects of the Debordian spectacle and Baudrillardian simulacra that dominate our lives today.

In seeking the future forms and actors of much-needed praxis, it is vital to pursue inclusivity, to invite as many thinkers and activists to the table of critical theory as possible. This book is working to that end, makes an important contribution to 
twenty-first century critical theory, and to philosophy and social theory in general, and it should readily reimagine itself in future volumes. A collection of essays like this would be fortifying to read every year.

Diana Boros

St. Mary's College of Maryland, St. Mary's City, MD 20686, USA dboros@smcm.edu 